\title{
Effect of ocean acidification on otolith development in larvae of a tropical marine fish
}

\author{
P. L. Munday ${ }^{1}$, V. Hernaman ${ }^{2}$, D. L. Dixson ${ }^{1}$, and S. R. Thorrold ${ }^{3}$ \\ ${ }^{1}$ ARC Centre of Excellence for Coral Reef Studies, and School of Marine and Tropical Biology, \\ James Cook University, Townsville, QLD 4811, Australia \\ ${ }^{2}$ Centre for Marine Studies, University of Queensland, Brisbane, QLD 4072, Australia \\ ${ }^{3}$ Biology Department, Woods Hole Oceanographic Institution, Woods Hole, MA 02543, USA
}

Received: 10 February 2011 - Published in Biogeosciences Discuss.: 7 March 2011

Revised: 2 June 2011 - Accepted: 9 June 2011 - Published: 22 June 2011

\begin{abstract}
Calcification in many invertebrate species is predicted to decline due to ocean acidification. The potential effects of elevated $\mathrm{CO}_{2}$ and reduced carbonate saturation state on other species, such as fish, are less well understood. Fish otoliths (earbones) are composed of aragonite, and thus, might be susceptible to either the reduced availability of carbonate ions in seawater at low $\mathrm{pH}$, or to changes in extracellular concentrations of bicarbonate and carbonate ions caused by acid-base regulation in fish exposed to high $p \mathrm{CO}_{2}$. We reared larvae of the clownfish Amphiprion percula from hatching to settlement at three $\mathrm{pH}_{\mathrm{NBS}}$ and $p \mathrm{CO}_{2}$ levels (control: $\mathrm{pH} 8.15$ and $404 \mu \mathrm{atm} \mathrm{CO}_{2}$; intermediate: $\mathrm{pH} 7.8$ and $1050 \mu$ atm $\mathrm{CO}_{2}$; extreme: $\mathrm{pH} 7.6$ and $1721 \mu$ atm $\mathrm{CO}_{2}$ ) to test the possible effects of ocean acidification on otolith development. There was no effect of the intermediate treatment $(\mathrm{pH}$ 7.8 and $1050 \mu$ atm $\mathrm{CO}_{2}$ ) on otolith size, shape, symmetry between left and right otoliths, or otolith elemental chemistry, compared with controls. However, in the more extreme treatment $\left(\mathrm{pH} 7.6\right.$ and $\left.1721 \mu \mathrm{atm} \mathrm{CO}_{2}\right)$ otolith area and maximum length were larger than controls, although no other traits were significantly affected. Our results support the hypothesis that $\mathrm{pH}$ regulation in the otolith endolymph can lead to increased precipitation of $\mathrm{CaCO}_{3}$ in otoliths of larval fish exposed to elevated $\mathrm{CO}_{2}$, as proposed by an earlier study, however, our results also show that sensitivity varies considerably among species. Importantly, our results suggest that otolith development in clownfishes is robust to even the more pessimistic changes in ocean chemistry predicted to occur by 2100 .
\end{abstract}

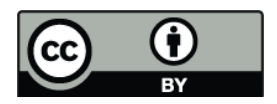

Correspondence to: P. L. Munday

(philip.munday@jcu.edu.au)

\section{Introduction}

Absorption of additional carbon dioxide $\left(\mathrm{CO}_{2}\right)$ from the atmosphere is causing ocean $\mathrm{pH}$ to decline and is reducing the availability of carbonate ions required by many marine species to form calcium carbonate $\left(\mathrm{CaCO}_{3}\right)$ shells and skeletons (Feely et al., 2004; Orr et al., 2005). As the saturation states of aragonite and calcite decline, the calcification rate of corals, molluscs, echinoderms and other invertebrates that secrete these forms of $\mathrm{CaCO}_{3}$ is predicted to decrease (Gattuso et al., 1998; Riebesell et al., 2000; Gazeau et al., 2007; Kleypas and Yates, 2009). If the current trajectory of global $\mathrm{CO}_{2}$ emissions is maintained, atmospheric $\mathrm{CO}_{2}$ concentrations could reach between 730-1020 ppm by the end of the century (Meehl et al., 2007; Raupach et al., 2007). This would cause ocean $\mathrm{pH}$ to decline $0.3-0.4$ units compared to current-day levels (Caldeira and Wickett, 2005) and reduce the concentration of carbonate ions in the shallow ocean by nearly $50 \%$ compared to the pre-industrial era. The consequences of such a reduction in carbonate ion concentration is likely to be serious for many calcifying species (HoeghGuldberg et al., 2007; Fabry et al., 2008; Doney et al., 2009; Hofmann et al., 2010). Possible impacts of elevated $\mathrm{CO}_{2}$ and ocean acidification on non-calcifying species, such as fishes, is still poorly known, but could potentially include effects on a range of physiological (Pörtner and Farrell, 2008), developmental (Pankhurst and Munday, 2011) and behavioural processes (Munday et al., 2009, 2010). Early life history stages are likely to be most vulnerable because physiological homeostasis might not be fully developed and their small body size makes them more sensitive to environmental variation (Ishimatsu et al., 2008; Melzner et al., 2009).

Published by Copernicus Publications on behalf of the European Geosciences Union. 
In general, marine fish appear to be relatively tolerant to mild increases in ambient $\mathrm{CO}_{2}$, presumably because welldeveloped mechanisms for acid-base regulation allow them to compensate for cellular acidosis caused by exposure to elevated $\mathrm{pCO}_{2}$ (Pörtner et al,. 2005; Ishimatsu et al., 2008; Melzner et al., 2009). A concern, however, is that fish otoliths (earbones) are composed of aragonite, and therefore, could be susceptible to the declining carbonate ion concentrations associated with ocean acidification. Just as calcification rates in corals decrease as the aragonite saturation state falls, it may become more difficult for fish to precipitate aragonite in their otoliths as the availability of carbonate ions in seawater declines. Alternatively, otolith growth may be affected by regulatory mechanisms used by fish to maintain their internal $\mathrm{pH}$ as ambient $p \mathrm{CO}_{2}$ increases. Changes in extracellular concentrations of carbonate and bicarbonate caused by acid-base regulation in a high $\mathrm{CO}_{2}$ environment could affect the precipitation of $\mathrm{CaCO}_{3}$ in the otolith (Payan et al., 1997). Indeed, one recent study reported that otoliths were larger in larval fishes exposed to elevated $\mathrm{CO}_{2}$, possibly because $\mathrm{pH}$ regulation caused carbonate concentrations to increase within the endolymph (Checkley et al., 2009). Maintenance of a steady $\mathrm{pH}$ within the endolymph, despite an influx of $\mathrm{CO}_{2}$, would increase the abundance of bicarbonate and carbonate ions in the endolymph, both of which could potentially be used in aragonite precipitation. Finally, physiological stress can also affect otolith size, shape, and the symmetry between left and right otoliths (Gagliano and McCormick, 2004; Payan et al., 2004). Thus, even if acidbase regulation or declining aragonite saturation state do not directly affect otolith development, increased stress caused by elevated $p \mathrm{CO}_{2}$ could potentially influence otolith shape and symmetry.

Changes to ocean chemistry associated with declining $\mathrm{pH}$, or changes in extracellular dissolved inorganic carbon (DIC) concentration due to acid-base regulation, could also affect otolith chemistry. The chemical composition of otoliths responds to environmental variation, including concentrations of elements in ambient water, temperature, and salinity (Campana and Thorrold, 2001). In many instances ambient water chemistry is the primary control on the incorporation of elements in otoliths, as evidenced by high correlations between the ratio of these elements to $\mathrm{Ca}$ at the site of otolith deposition and their concentration in the external environment (e.g. Bath et al., 2000; Martin and Thorrold, 2005). Bicarbonate ion concentration and $\mathrm{pH}$ has been shown to influence $\mathrm{Sr}$, but not $\mathrm{Mg}$, incorporation in calcitic foraminifera (Dissard et al., 2010). However, the effect of changes in aqueous carbonate chemistry on fish otolith composition remains unknown.

Fish ears detect sound, body orientation and acceleration from the position of the otoliths in the inner ear and movement of the otoliths over sensory hair cells (Helfman et al., 1997; Popper and Lu 2000). Any substantial change to the size, shape, or symmetry of otoliths could have serious im- plications for individual performance and survival (Gagliano et al., 2008). To date, two studies have examined the potential effects of ocean acidification on otolith growth and development. Checkley et al. (2009) found that otolith size increased in larval seabass exposed to $\sim 1000 \mu$ atm $\mathrm{CO}_{2}$ for eight days. In contrast, Munday et al. (2011) detected no effects of $\sim 850 \mu$ atm $\mathrm{CO}_{2}$ on size, shape or symmetry of otoliths on juvenile spiny damselfish, a species without a larval phase. No studies have investigated the possible effects of ocean acidification on otolith chemistry. We reared larvae of a model species, the clownfish Amphiprion percula, through their entire larval phase at two ocean acidification scenarios to test if exposure to elevated $p \mathrm{CO}_{2}$ and reduced carbonate ion concentrations affects otolith size, shape, symmetry (between left and right otoliths) and otolith chemistry compared with current-day controls. The experimental conditions are consistent with more extreme scenarios for the years $2100\left(\mathrm{pH} 7.8\right.$ and $\left.1050 \mu \mathrm{atm} \mathrm{CO}_{2}\right)$ and $2200-2300(\mathrm{pH}$ 7.6, $1721 \mu \mathrm{atm} \mathrm{CO}_{2}$ ) based on a business-as-usual trajectory of $\mathrm{CO}_{2}$ emissions (Caldeira and Wickett, 2005; Meehl et al., 2007). This combination of treatments allowed us to test the susceptibility of otolith development in clownfish to changes in seawater chemistry and to investigate potential mechanisms involved.

\section{Materials and methods}

\subsection{Larval rearing}

Clownfish were reared in a 700001 recirculating seawater system at James Cook University's experimental marine aquarium facility. Four adult breeding pairs were kept in separate 701 aquariums supplied with a continuous flow of filtered seawater at $181 \mathrm{~h}^{-1}$. Breeding pairs laid eggs on the underside of a terracotta pot placed in their aquarium. Pots were checked each morning for the presence of eggs. On discovering a new clutch of eggs, the parental aquarium was assigned to one of three $\mathrm{pH}_{\mathrm{NBS}}$ levels (8.15 (control), 7.8, 7.6) and $\mathrm{pH}$ adjusted as described below. The breeding pairs produced new egg clutches on a 2-4 week cycle. The $\mathrm{pH}$ treatment assigned to each clutch was alternated so that each of the four parents were assigned to each $\mathrm{pH}$ treatment during the experiment. On the evening of hatching (6-8 days after laying) the egg clutch was removed from the parental aquarium and transferred to a 1001 larval rearing aquarium set to the same $\mathrm{pH}$ as the parental aquarium. Eggs hatched within several hours of darkness. Larvae were reared in a semi-closed system, where each aerated aquarium had no water flow during the day and was then slowly flushed with filtered seawater each night. This daily cycle ensured that larvae could feed ad-libitum throughout daylight hours and that any unconsumed food was removed each night. Larvae were fed rotifers (Brachionus sp.) at 5 individuals $\mathrm{ml}^{-1}$ each morning for the first three days. Artemia naupli were added 
at 1 individual $\mathrm{ml}^{-1}$ each morning from day three. The ratio of Artemia naupli to rotifers was increased each day until larvae were only fed 5 Artemia naupli $\mathrm{m}^{-1}$ from 8 days posthatching. A summer light cycle of $13 \mathrm{~h}$ light/11 h dark was simulated with fluorescent lights. Larvae were reared to the end of their larval phase (11-d post hatching), at which time behaviour consistent with competency to settle (attraction to the sides of the rearing aquarium) and the appearance of benthic colouration was observed.

Settlement stage larvae (11-d post hatching) were sacrificed with a lethal dose of clove oil anaesthetic (Munday and Wilson, 2007). Larvae from one breeding pair in the control group, and a different breeding pair in the $\mathrm{pH} 7.8$ group, did not survive, therefore each treatment contained larvae from at least three of the four parental genotypes. A sample of 10-15 larvae from each clutch were stored in $75 \%$ ethanol for otolith analysis. The remaining larvae were stored in formaldehyde for other analyses.

\subsection{Seawater manipulation}

Seawater $\mathrm{pH}$ in the parental aquariums and larval rearing tanks that had been allocated to the 7.8 or 7.6 treatments was adjusted by $\mathrm{CO}_{2}$ injection. A separate $\mathrm{pH}$-controller (Tunze Aquarientechnik, Germany) was attached to each aquarium to maintain $\mathrm{pH}$ at the desired level. The $\mathrm{pH}$ controller was connected to a laboratory-grade glass $\mathrm{pH}$ probe in the aquarium and to an electronic solenoid connected to a cylinder of $\mathrm{CO}_{2}$. The solenoid injected a slow stream of $\mathrm{CO}_{2}$ into a diffuser (Red Sea Reactor 500) at the bottom of the aquarium whenever the $\mathrm{pH}$ of the aquarium seawater rose above the set point. A precision needle valve inserted before the solenoid was adjusted to ensure a slow, steady, delivery of $\mathrm{CO}_{2}$ into the diffuser. Using this method is was possible to constantly maintain $\mathrm{pH}$ within \pm 0.05 units of the desired level and there was no detectable gradient in seawater $\mathrm{pH}$ within the aquarium. A diffuser without $\mathrm{CO}_{2}$ injection was placed in each aquarium and rearing tank assigned to control conditions. The $\mathrm{pH}_{\mathrm{NBS}}$ of each aquarium was independently checked each day using a WP80 pH meter (TPS, Australia) calibrated with fresh $\mathrm{pH}$ buffers (Merk, Germany). $\mathrm{CO}_{2}$ was only injected into aquariums to adjust $\mathrm{pH}$ when eggs or larvae were present. All water returned to a 600001 sump where it was degassed by stirring and using a 10001 algal bio-remediation tank. Water temperature was maintained at $30^{\circ} \mathrm{C} \pm 0.6$ (SD) using electric heaters. Oxygen saturation was checked regularly with an Oxi 340i oxygen probe (WTW, Germany) and was always above $90 \%$.

Total alkalinity $\left(\mathrm{A}_{\mathrm{T}}\right)$ of seawater at each $\mathrm{pH}$ level was measured weekly by titration. Average $p \mathrm{CO}_{2}$, bicarbonate and carbonate ion concentrations were then estimated from $\mathrm{pH}$ and $\mathrm{A}_{\mathrm{T}}$ in the program CO2SYS, using the constants of Millero et al. (2006). All seawater chemistry parameters are shown in Table 1. Average $p \mathrm{CO}_{2}$ for the 8.15 (control), 7.8 and $7.6 \mathrm{pH}$ treatments was estimated to be 404, 1050 and $1721 \mu$ atm, respectively.

\subsection{Otolith morphometrics and Fourier shape analysis}

Larvae were removed from the preservative, blotted dry, weighed (nearest $\mathrm{mg}$ ) and photographed in a lateral position under a stereomicroscope. Standard length (SL) to nearest $0.01 \mathrm{~mm}$ was estimated for each fish from the digital photograph using image analysis (Optimas 6.5, Media Cybernetics). Sagittal otoliths were then removed and stored dry in well-plates. The left and right otolith of each individual was photographed to produce a calibrated, grey-scale image. Morphometric measurements (otolith area, $\mu \mathrm{m}^{2}$; maximum length, $\mu \mathrm{m}$; maximum breadth, $\mu \mathrm{m}$; rectangularity; circularity) and Fast Fourier descriptor were obtained from the images using Optimas. An automatic pixel gradient traced anticlockwise around the silhouette of the otolith, starting from a common landmark (distal edge of the rostrum). Fourier analysis reproduces the outline of a shape by considering it to be an aggregate of simple wave forms, describable by a series of sine and cosine curves (Younker and Ehrlich, 1977). Optimas provided a complex $\left(a+b_{i}\right)$ Cartesian fast Fourier transformation of the $\mathrm{x}-\mathrm{y}$ coordinates of 128 equidistant points around the otolith outline. The complex Fourier descriptors were converted $\left(\sqrt{ } a^{2}+\sqrt{ } b^{2}\right)$ to an absolute value for each harmonic (Lestrel, 1997). The images of the right otoliths were flipped horizontally so that the 128 sampling points were measuring the same part of the otolith for left and right otoliths.

To remove any confounding effect of otolith image position or size from the data, the Fourier descriptors were standardized for differences in otolith position by setting the zeroth harmonic $\left(\mathrm{H}_{0}\right)$ to $0+0_{i}$, and for differences in otolith size by dividing all successive harmonics by the first harmonic $\left(\mathrm{H}_{1}\right)$. Greater than $97.0 \%$ of the variance in otolith shape was accounted for by the first 19 standardized harmonics $\left(\mathrm{H}_{2}-\mathrm{H}_{20}\right)$ in all instances ( $>99.0 \%$ in most instances). Consequently, we restricted our analysis to these standardized harmonics.

Morphometric measurements were calculated for 16 randomly selected individuals from each treatment and Fast Fourier coefficients were calculated for 19 randomly selected individuals from each treatment (Table 2). Samples at each treatment level contained 3-10 individuals from at least 3 different breeding pairs.

\subsection{Otolith chemistry}

Elemental chemistry of otoliths was quantified using laser ablation inductively coupled plasma mass spectrometry. Otolith chemistry was conducted on 5-7 randomly selected individuals from each treatment. One otolith chosen at random from each fish was mounted on a microscope slide with a cyanoacrylic glue, ground to the midplane using 
Table 1. Average ( \pm SD where estimated) seawater chemistry parameters over the duration of the experiment for the nominated $\mathrm{pH}$ treatments. Salinity $(S)$, temperature $(T)$ and total alkalinity $\left(A_{\mathrm{T}}\right)$ were measured directly. All other parameters were estimated in the program CO2SYS.

\begin{tabular}{rrrrrrrrrr}
\hline $\mathrm{pH}_{\mathrm{NBS}}$ & $\begin{array}{r}S \\
\mathrm{ppt}\end{array}$ & $\begin{array}{r}T \\
{ }^{\circ} \mathrm{C}\end{array}$ & $\begin{array}{r}A_{\mathrm{T}} \\
\mu \mathrm{mol} \mathrm{kg}\end{array}$ & $\begin{array}{r}\mathrm{DIC} \\
\mu \mathrm{mol} \mathrm{kg}{ }^{-1}\end{array}$ & $\begin{array}{r}p \mathrm{CO}_{2} \\
\mu \mathrm{atm}\end{array}$ & $\begin{array}{r}\mathrm{CO}_{2} \\
\mu \mathrm{mol} \mathrm{kg}{ }^{-1}\end{array}$ & $\begin{array}{r}\mathrm{HCO}_{3}^{-} \\
\mu \mathrm{mol} \mathrm{kg}\end{array}$ & $\begin{array}{r}\mathrm{CO}_{3}^{2-} \\
\mu \mathrm{mol} \mathrm{kg}^{-1}\end{array}$ & $\begin{array}{r}\Omega \mathrm{Ar}^{-1} \\
\end{array}$ \\
\hline 8.15 & 33 & $30(0.6)$ & $2043(131)$ & 1768 & 404.1 & 10.24 & 1567.22 & 190.45 & 3.14 \\
7.8 & 33 & $30(0.6)$ & $2066(116)$ & 1946 & 1050.8 & 26.64 & 1820.68 & 98.83 & 1.63 \\
7.6 & 33 & $30(0.6)$ & $2042(132)$ & 1990 & 1721.4 & 43.63 & 1881.85 & 65.01 & 1.06 \\
\hline
\end{tabular}

Table 2. Fish sample sizes and dimensions used in morphometric and Fourier analyses.

\begin{tabular}{lcccc}
\hline Treatment & \multicolumn{2}{c}{ Morphometrics } & Fourier \\
\hline & $\mathrm{n}$ & \multicolumn{2}{c}{ Fish standard length $(\mathrm{mm})$} & $\mathrm{n}$ \\
\cline { 3 - 4 } & & \multicolumn{2}{c}{ Mean $( \pm$ SD) } & Range \\
& & \\
\hline pH 8.15 & 16 & $7.2( \pm 1.75)$ & $5.2-10.6$ & 19 \\
pH 7.8 & 16 & $8.0( \pm 1.22)$ & $6.0-9.7$ & 19 \\
pH 7.6 & 16 & $6.9( \pm 1.22)$ & $5.6-9.0$ & 19 \\
\hline
\end{tabular}

$3 \mu \mathrm{ml}_{2} \mathrm{O}_{3}$ lapping film, sonified in ultrapure water for $2 \mathrm{~min}$ and then dried under a laminar flow hood in a class 100 cleanroom. Cleaned otoliths were then remounted onto a petrographic slide (8 otoliths per slide) using double-sided tape and stored in plastic bags for transportation to the ICP-MS facility at the Woods Hole Oceanographic Institution. Sectioned otoliths were analyzed with a $193 \mathrm{~nm}$ excimer laser coupled with a Thermo Finnigan Element 2 high resolution ICP-MS. We sampled a $80 \mu \mathrm{m}$ spot centered approximately $50 \mu \mathrm{m}$ outside of the nucleus using a laser repetition rate of $5 \mathrm{~Hz}$ at $70 \%$ power and a dwell time of $60 \mathrm{~s}$. A He gas stream carried ablated material from the ablation chamber to the ICP-MS where it was mixed with an Ar sample gas and a wet aerosol $\left(2 \% \mathrm{HNO}_{3}\right)$ supplied by a self-aspirating $\left(20 \mu \mathrm{min}^{-1}\right)$ PFA nebulizer in the concentric region of the quartz dual inlet spray chamber. Initial testing found that isotopes from six elements $\left({ }^{7} \mathrm{Li},{ }^{25} \mathrm{Mg},{ }^{43} \mathrm{Ca},{ }^{55} \mathrm{Mn},{ }^{88} \mathrm{Sr}\right.$ and ${ }^{138} \mathrm{Ba}$ ) had count rates significantly higher than blank values and were free of isobaric interferences. Instrument blanks $\left(2 \% \mathrm{HNO}_{3}\right)$ and a otolith certified reference material (Sturgeon et al. 2005), dissolved in $2 \% \mathrm{HNO}_{3}$ and diluted to a final Ca concentration of $8 \mu \mathrm{g} . \mathrm{g}^{-1}$, were run every eight samples and used to correct for blank values and instrument mass bias, respectively, following FitzGerald et al. (2004). Detection limits were calculated as 3 standard deviations of the blanks that were run periodically throughout the analyses $(n=3)$. These limits were $5 \%$ of the average sample intensity for ${ }^{7} \mathrm{Li}, 3 \%$ of ${ }^{25} \mathrm{Mg}, 0.01 \%$ for ${ }^{43} \mathrm{Ca}, 8 \%$ for ${ }^{55} \mathrm{Mn}$,
$0.004 \%$ for ${ }^{88} \mathrm{Sr}$, and $7 \%$ for ${ }^{138} \mathrm{Ba}$. We estimated external precision (relative standard deviation, RSD) of the analyses by running a powdered otolith lab standard, dissolved in $2 \%$ $\mathrm{HNO}_{3}$ and diluted to a Ca concentration of $8 \mu \mathrm{g} . \mathrm{g}^{-1}$. Estimates of $\operatorname{RSD}(n=3)$ were $2.2 \%$ for $\mathrm{Li}: \mathrm{Ca}, 1.7 \%$ for $\mathrm{Mg}: \mathrm{Ca}$, $14 \%$ for $\mathrm{Mn}: \mathrm{Ca}, 0.5 \%$ for $\mathrm{Sr}: \mathrm{Ca}$ and $0.6 \%$ for $\mathrm{Ba}: \mathrm{Ca}$.

\subsection{Statistical analyses}

\subsubsection{Otolith size and shape}

Fish size could potentially influence otolith size and shape, therefore, we first examined the relationship between SL and each of the otolith morphometric traits. Otolith circularity was the only trait that exhibited a significant relationship with SL and ANCOVA was used to determine if this morphometric trait differed among $\mathrm{pH}$ treatments, using fish standard length as the covariate. There was no relationship between SL and the other otolith traits. ANOVA was used to compare otolith breadth and rectangularity differed among $\mathrm{pH}$ treatments. The variance distributions for otolith area and maximum length were not homogeneous (Levene's test: $P<0.05)$ and were not improved by transformations. Therefore, non-parametric Kruskal-Wallis median tests were used to determine if these morphometric traits differed among $\mathrm{pH}$ treatments.

\subsubsection{Size difference within otolith pairs}

To investigate directional asymmetry of the otoliths (i.e. is the right or left otolith usually larger), signed differences in otolith morphometrics were obtained by subtracting the value for the left otolith from that of the right otolith (RL) for otolith area, maximum length, and maximum breadth. This was not conducted for rectangularity and circularity because it is the absolute values of these parameters that have meaning. The frequency of positive versus negative scores among the $\mathrm{pH}$ treatments was then compared with a chisquare test of independence for each measure of otolith size.

To determine if $\mathrm{pH}$ treatment affected the magnitude of otolith asymmetry with respect to otolith area, maximum length, and maximum breadth, we used ANOVA to compare unsigned differences between left and right otoliths for these 
traits. ANCOVA was not required as there was no relationship between SL and unsigned differences for any of these traits. Unsigned differences in area and maximum length were $\log$ transformed to meet assumptions of homogeneity of variances.

\subsubsection{Fourier analysis of otolith asymmetry}

To investigate differences in the degree of asymmetry among treatments, unsigned differences between right and left otoliths in the standardised harmonic amplitude were obtained for each harmonic number. The data were analysed in two ways. First, a Kruskal-Wallis test was performed on the unsigned differences in standardised harmonic amplitudes for each harmonic number (shape descriptors). Parametric tests were not used because transformation of data did not produce normality. Second, a one-way between-groups multivariate analysis of variance (MANOVA) was performed using the unsigned differences between right and left otoliths in harmonic numbers $\mathrm{H}_{2}$ to $\mathrm{H}_{20}$ (shape descriptors) as dependent variables. The assumption of multivariate normality was checking by confirming normality for each of the dependent variables. The multivariate data were visualised using nonmetric multidimensional scaling (MDS), which is presented with a stress coefficient that reflects how well the data have been reduced to two dimensions.

\subsubsection{Otolith chemistry}

A one-way MANOVA was used to compare multivariate elemental signatures among treatments. Assumptions of multivariate normality and homogenenity of covariance matrices were confirmed as above.

\section{Results}

\subsection{Otolith morphometrics}

\subsubsection{Otolith size and shape}

There was a significant difference among $\mathrm{pH}$ treatments in mean otolith area (left otoliths only) and otolith maximum length (left and right otoliths) (Table 3; Fig. 1). One-tailed $\mathrm{t}$-tests (assuming unequal variance) revealed that mean area of otoliths in the 7.6 treatment was larger than controls for left otoliths $(P=0.02)$, but not right otoliths $(P=0.11)$ and that maximum length of otoliths in the 7.6 treatment was larger than controls for both left $(P=0.01)$ and right otoliths $(P=0.03)$. On average otoliths in the 7.6 treatment had a $15 \%$ greater area and were $10 \%$ longer than otoliths from control fish. There was also an apparent trend for otolith breadth to be larger in the 7.6 treatment (Fig. 1), however, this was not statistically significant (Table 3 ). In contrast to the 7.6 treatment, there were no apparent differences in av-
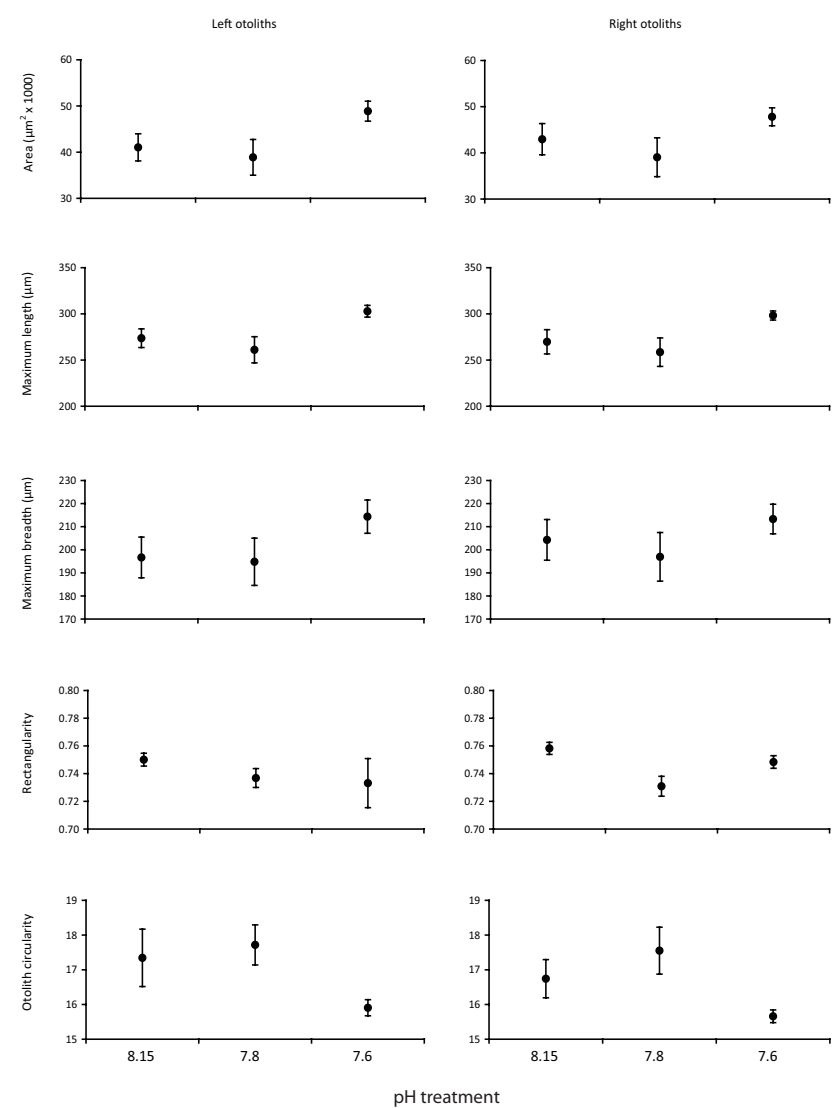

Fig. 1. Mean $( \pm S E)$ otolith area, maximum length, maximum breadth, rectangularity and circularity for left and right otoliths of larval clownfish reared at $\mathrm{pH}_{\mathrm{NBS}}$ 8.15, 7.8, and 7.6.

erage size or shape of otoliths in the 7.8 treatment compared with controls (Fig. 1).

There was a statistically significant effect of $\mathrm{pH}$ treatment on otolith rectangularity for right otoliths only (Table 3), with a lower rectangularity value in the $\mathrm{pH} 7.8$ treatment compared with controls $(P=0.003)$. However, the difference in the two values ( 0.76 and 0.73 for control and 7.8 respectively) represents a negligible difference in otolith shape, and there was no difference in shape between the $\mathrm{pH} 7.6$ treatment and the controls. Therefore, this significant result does not appear to be causally related to the $\mathrm{pH}$ treatment. There was no significant effect of $\mathrm{pH}$ treatment on otolith circularity (Table 3), although there was a trend for decreased circularity for both left and right otoliths in the 7.6 treatment (Fig. 1).

Variation around the mean was lower in the $\mathrm{pH} 7.6$ group for otolith area, maximum length and circularity (with one outlying value excluded) for both left and right otoliths (Fig. 1). This suggests that otoliths in this treatment were a more consistent size and shape than otoliths in the control and 7.8 groups. 
Table 3. Results of Kruskal-Wallis median test (area, maximum length), ANOVA (breadth, rectangularity) and ANCOVA (circularity) for left and right otoliths of larval clownfish reared at three $\mathrm{pH}$ treatments $(8.15,7.8$, and 7.6). Fish standard length (SL) is the covariate for ANCOVA.

\begin{tabular}{|c|c|c|c|c|}
\hline Variable & Source & d.f. & $\chi^{2}$ or $F$ value & $P$ \\
\hline \multicolumn{5}{|l|}{ (a) Left otoliths } \\
\hline Otolith area & $\mathrm{pH}$ treatment & 2 & $\chi^{2}=6.00$ & 0.049 \\
\hline Otolith maximum length & $\mathrm{pH}$ treatment & 2 & $\chi^{2}=9.50$ & 0.009 \\
\hline Otolith maximum breadth & $\mathrm{pH}$ treatment & 2 & 1.488 & 0.237 \\
\hline Otolith rectangularity & $\mathrm{pH}$ treatment & 2 & 0.62 & 0.54 \\
\hline \multirow[t]{2}{*}{ Otolith circularity } & $\mathrm{pH}$ treatment & 2 & 1.280 & 0.288 \\
\hline & Fish SL & 1 & 59.70 & 0.000 \\
\hline \multicolumn{5}{|l|}{ (b) Right otoliths } \\
\hline Otolith area & $\mathrm{pH}$ treatment & 2 & $\chi^{2}=0.50$ & 0.778 \\
\hline Otolith maximum length & $\mathrm{pH}$ treatment & 2 & $x^{2}=6.00$ & 0.049 \\
\hline Otolith maximum breadth & $\mathrm{pH}$ treatment & 2 & 0.878 & 0.422 \\
\hline Otolith rectangularity & $\mathrm{pH}$ treatment & 2 & 6.31 & 0.004 \\
\hline \multirow[t]{2}{*}{ Otolith circularity } & $\mathrm{pH}$ treatment & 2 & 1.32 & 0.277 \\
\hline & Fish SL & 1 & 40.84 & 0.000 \\
\hline
\end{tabular}

Mean SL (mm) of larvae was not significantly different among treatments (ANOVA: $F_{2,45}=2.667, P=0.08$ ), however there was some variation in SL within treatments (Table 2). There was a highly significant effect of SL on otolith circularity for both left and right otoliths (Table 3). Regression analysis revealed a positive linear relationship between otolith circularity and fish standard length (left otoliths: $\mathrm{y}=1.457 \mathrm{x}+6.507 ; r^{2}=0.517$; right otoliths: $\left.\mathrm{y}=1.060 \mathrm{x}+8.880 ; r^{2}=0.522\right)$. Circularity is defined as otolith perimeter ${ }^{2}$ otolith area. The minimum value of 4pi (12.75) is achieved only for a circular boundary, with values of $\sim 16$ for a square boundary, and $\sim 20$ for a triangular boundary. Circularity increased from $\sim 15$ in the smallest fish $(5-6 \mathrm{~mm} \mathrm{SL})$ to $>20$ in the largest fish $(9-11 \mathrm{~mm} \mathrm{SL})$ indicating a shift from a square-shaped boundary towards a more triangular shape with increasing fish length.

\subsubsection{Size difference within otolith pairs}

There was no evidence of directional asymmetry, with either the left or the right otolith being the largest of a pair, and no difference in the distribution of positive and negative asymmetry among treatments for any of the otolith measurements (Chi-square $P>0.15$ in all cases). Similarly, there was no significant difference among $\mathrm{pH}$ treatments in the magnitude of otolith asymmetry with respect to otolith area $(P=0.24)$, maximum length $(P=0.79)$, or maximum breadth $(P=0.79)$, although there was a tendency for the magnitude of difference between left and right otoliths be less in the 7.6 treatment compared to the controls and 7.8 treatment (Fig. 2). As observed above in the morphometric analysis, variation around the mean value was lower in the $\mathrm{pH} 7.6$ group compared to the controls and $\mathrm{pH} 7.8$ group.

\subsubsection{Fourier analyses of otolith asymmetry}

There were no significant differences among $\mathrm{pH}$ treatments in the Fourier descriptors of otolith shape, either when harmonic numbers were analysed individually (Kruskal-Wallis test $P>0.05$ in all cases, except $\mathrm{H}_{13}$ ) or in the multivariate analysis of all 19 harmonic numbers (MANOVA $\mathrm{F}_{38,72}=1.10, P=0.357$, Wilks' Lambda $\left.=0.4\right)$. The similarity among treatments, based on the combination of all harmonic numbers, was clearly evident in the MDS plot (Fig. 3). For $\mathrm{H}_{13}$ there was a significant difference in median harmonic amplitude between the control and $\mathrm{pH} 7.8$ treatment (Mann-Whitney $\mathrm{U}$ test $P=0.02$ ), but no difference in any other pairwise comparison.

\subsection{Otolith chemistry}

Minor and trace element chemistry of larval clownfish otoliths appeared unaffected by the $\mathrm{pH}$ of ambient water in which they were reared. A one-way MANOVA found no significant differences in elemental signatures of otoliths among treatments (MANOVA $\mathrm{F}_{10,22}=1.07, P=0.42$, Wilks' Lambda $=0.45$ ). Similarly, there were no consistent patterns in any of the individual elemental ratios as a function of $\mathrm{pH}$ (Fig. 4). 

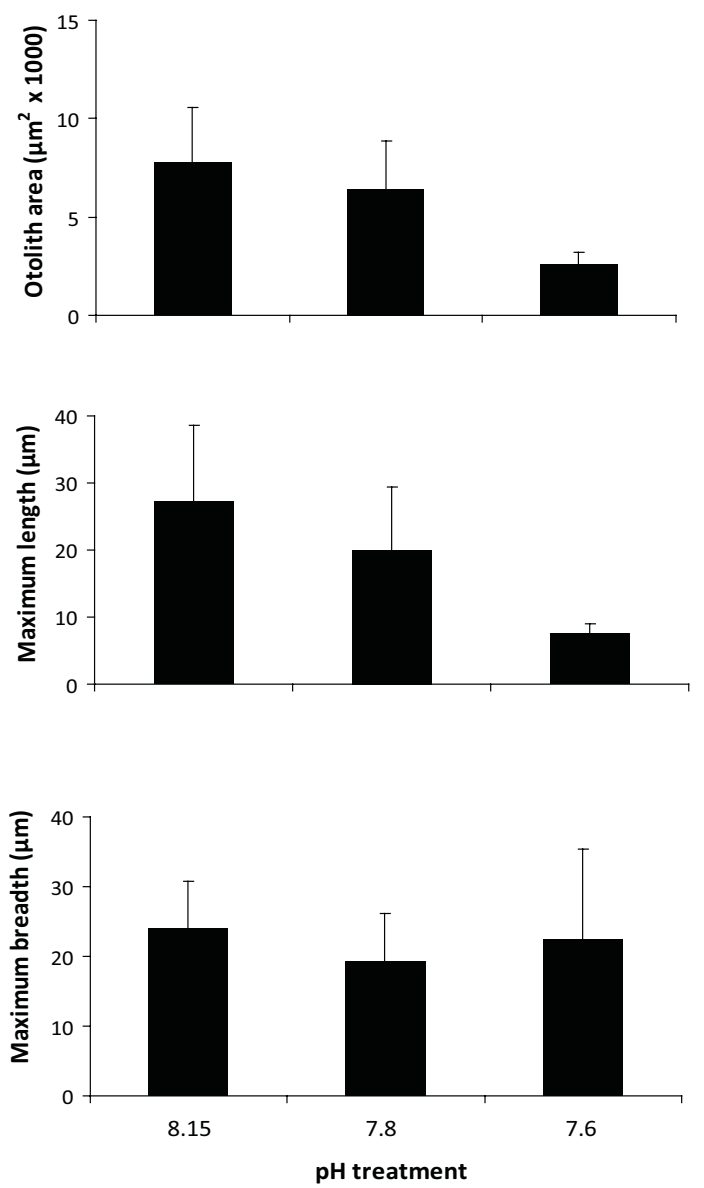

Fig. 2. Mean ( \pm SE) unsigned differences in area, maximum length and maximum breadth between left and right otoliths of larval clownfish reared at $\mathrm{pH}_{\mathrm{NBS}} 8.15,7.8$, and 7.6.

\section{Discussion}

We found that the size, shape, symmetry and elemental chemistry of otoliths in larval clownfish was unaffected by exposure to simulated levels of ocean acidification that could occur at the end of this century under a business-as-usual scenario of $\mathrm{CO}_{2}$ emissions ( $\mathrm{pH} 7.8$ and $1050 \mu$ atm $\mathrm{CO}_{2}$ ). However, in a more extreme treatment $(\mathrm{pH} 7.6$ and $1721 \mu$ atm $\mathrm{CO}_{2}$ ) otolith area and maximum length were larger than control otoliths. Two other recent studies have examined potential effects of ocean acidification on fish otoliths. Checkley et al. (2009) detected increased otolith size in larval seabass, Atractoscion nobilis, exposed to elevated $\mathrm{CO}_{2}$ during the egg stage and up to 8 days post-hatching. Otoliths area was 79\% and 15-17\% larger than controls for fish reared at 993 and $2558 \mu \mathrm{atm} \mathrm{CO}_{2}$, respectively. In contrast, Munday et al. (2011) did not detect any effect of elevated $\mathrm{CO}_{2}$ on otolith size of juvenile spiny damselfish, Acanthochromis polyacanthus, reared for 3 weeks in treatments up to $841 \mu \mathrm{atm} \mathrm{CO}_{2}$. The different results of these two studies could have been due
$\Delta$

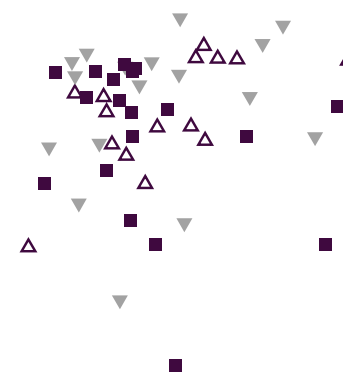

$\triangle \mathrm{pH} 8.15$

$\nabla \mathrm{pH} 7.8$

$\Delta$

pH 7.6
$\Delta$

$\Delta$
Fig. 3. MDS plot of Fourier descriptors of otolith shape for each individual sampled, grouped by $\mathrm{pH}$ treatment.

to: (1) the higher $p \mathrm{CO}_{2}$ levels used by Checkley et al. (2009), (2) the absence of a larval phase in the spiny damselfish, which could make them less susceptible to elevated $\mathrm{CO}_{2}$, or (3) different durations of the two experiments. Our results presented here suggest that otolith size can indeed by affected by reduced $\mathrm{pH}$ and elevated $p \mathrm{CO}_{2}$, as proposed by Checkley et al. (2009), however, sensitivity varies among species. Clownfish otoliths were not affected at $\sim 1000 \mu$ atm $\mathrm{CO}_{2}$, whereas seabass otoliths were significantly larger at this concentration, but otoliths of both species were larger at higher $p \mathrm{CO}_{2}$ concentrations. Thus, elevated $p \mathrm{CO}_{2}$ appears to affect otolith development in both species, but larval clownfishes are more tolerant of elevated $\mathrm{CO}_{2}$ than larval seabass. There is increasing evidence that ocean acidification affects different calcifying species in very different ways (Langer et al., 2009; Ries et al., 2009; Dupont et al., 2010; Kroeker et al., 2010) and these results indicate that the same types of variation might be observed among species without extensive carbonate skeletons.

The variable responses observed among the three species studied to date may be related to their life histories. The spiny damselfish, Acanthochromis polyacanthus, studied by Munday et al. (2010) has direct developing juveniles that remain on the reef after hatching. Juveniles shelter with their parents in small caves, where $\mathrm{CO}_{2}$ levels are likely to become elevated due to respiration. Consequently, newly hatched A. polyacanthus may be adapted to periods of high ambient $\mathrm{CO}_{2}$. The clownfish, Amphiprion percula, has pelagic larvae, but is a demersal spawner. Benthic eggs are likely to experience significant fluxes in ambient $\mathrm{CO}_{2}$ due to consumption of $\mathrm{CO}_{2}$ by photosynthesis during the day and release of $\mathrm{CO}_{2}$ by respiration of reef organisms at night (Munday et al., 2008). Hatching from benthic eggs may precondition larval clownfishes to moderate increases in ambient $\mathrm{CO}_{2}$. In contrast, the seabass Atractoscion nobilis is a pelagic spawner, so both eggs and larvae are likely adapted to the relatively 


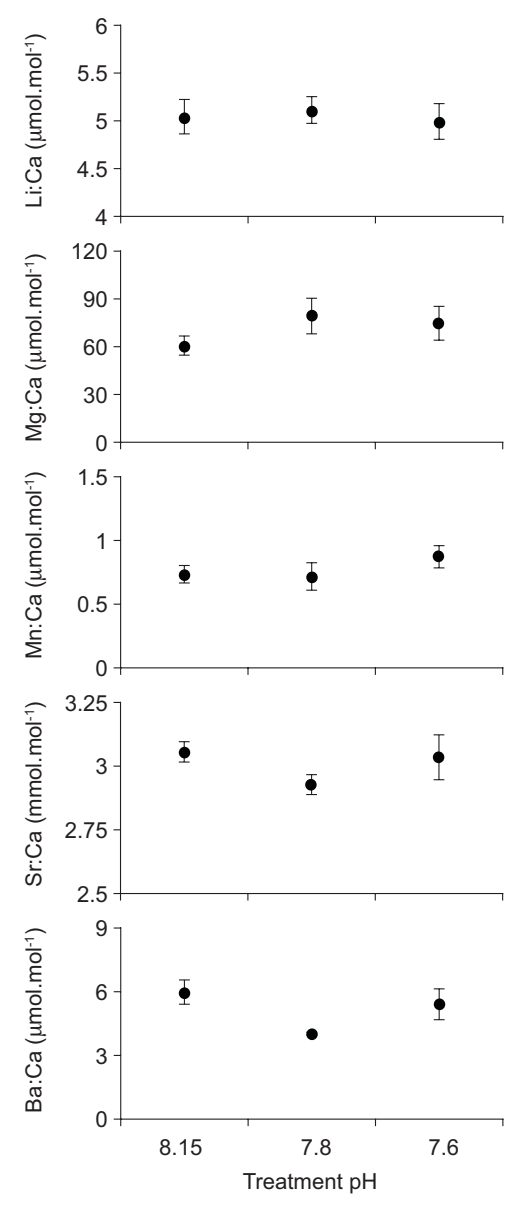

Fig. 4. Mean ( $\pm \mathrm{SE}) \mathrm{Li}: \mathrm{Ca}, \mathrm{Mg}: \mathrm{Ca}, \mathrm{Mn}: \mathrm{Ca}, \mathrm{Sr}: \mathrm{Ca}$ and $\mathrm{Ba}: \mathrm{Ca}$ ratios in otoliths of larval clownfish reared at $\mathrm{pH}_{\mathrm{NBS}} 8.15(n=7), 7.8$ $(n=5)$, and $7.6(n=6)$.

low and stable $\mathrm{CO}_{2}$ environment characteristic of epipelagic ocean waters, and may be more susceptible to elevated $\mathrm{CO}_{2}$. Further studies on a range of benthic and pelagic spawners are required to test this hypothesis.

If reduced seawater carbonate ion $\left(\mathrm{CO}_{3}^{2-}\right)$ concentrations affected the rate of otolith precipitation we would expect to see a decline in otolith size in acidified seawater. Instead there was a trend for otolith size to increase in these conditions. Fish actively regulate their acid-base balance through bicarbonate $\left(\mathrm{HCO}_{3}^{-}\right)$accumulation and ion exchange across the gills (Claiborne et al., 2002; Evans et al., 2005; Brauner and Baker, 2009) and, thus, are able to compensate for intra- and extra-cellular acidosis caused by increased $p \mathrm{CO}_{2}$. Changes to extracellular $\mathrm{HCO}_{3}^{-}$and $\mathrm{CO}_{3}^{2-}$ concentrations caused by acid-base regulation at high $p \mathrm{CO}_{2}$ could potentially influence the precipitation of $\mathrm{CaCO}_{3}$ in structures such as otoliths (Payan et al., 1997). Checkley et al. (2009) proposed that larval fish controlled the concentration of $\mathrm{H}^{+}$and $\mathrm{Ca}^{2+}$ ions in the blood plasma and endolymph (the fluid surrounding an otolith), but not the neutral molecule $\mathrm{CO}_{2}$. Con- sequently, maintenance of a constant $\mathrm{pH}$ in the endolymph despite elevated extracellular $p \mathrm{CO}_{2}$ would lead to increased $\mathrm{CO}_{3}^{2-}$ concentrations in the endolymph due to diffusion of $\mathrm{CO}_{2}$ from blood plasma across the endolyphatic membrane. Increased $\mathrm{CO}_{3}^{2-}$ concentrations in the endolymphatic fluid may, in turn, increase the rate of aragonite precipitation at the otolith surface. However, $\mathrm{CO}_{2}$ concentrations are generally higher in endolymphic fluid than in blood plasma (Takagi, 2002), perhaps related to the removal of $\mathrm{H}^{+}$ions produced during disassociation of $\mathrm{HCO}_{3}^{-}$to $\mathrm{CO}_{3}^{2-}$ at the time of aragonite precipitation (Payan et al., 1999). Under this scenario there would be net diffusion of $\mathrm{CO}_{2}$ out of, not into, the endolymph. Alternatively, $\mathrm{HCO}_{3}^{-}$accumulation as a result of acid-base compensation, either in the plasma or endolymph, may promote otolith accretion if $\mathrm{HCO}_{3}^{-}$is the preferred dissolved inorganic carbon species for calcification (Allemand et al., 2007; Herfort et al., 2008). The precise mechanisms involved in acid-base regulation in larval marine fishes are not fully understood (Brauner, 2009), nor are the cellular mechanisms involved in calcification of many marine species (Hofmann et al., 2010). Nonetheless, acid-base regulation and biological control of endolymph $\mathrm{pH}$ are likely to be central to the changes in otolith growth observed in these two species of fish when exposed to high $\mathrm{CO}_{2}$ (Romanek and Gauldie, 1996; Payan et al., 1997, 1998; Allemand et al. 2007).

Otoliths have an important role in fish hearing and body orientation. However, if the changes in otolith area and maximum length that we observed in the highest $\mathrm{CO}_{2}$ treatment $\left(\mathrm{pH} 7.6,1721 \mu \mathrm{atm} \mathrm{CO}_{2}\right)$ would be sufficient to affect these important functions is unknown. Otolith size can vary considerably among individual fish of the same somatic size, and otoliths of some species continue to grow even once somatic growth has ceased (Campana, 1990; Thorrold and Hare, 2002; Munday et al., 2004). Furthermore, we observed considerable variation in otolith morphometric traits among individuals in the control and less extreme $\mathrm{CO}_{2}$ groups. Therefore, some variation in otolith size is commonplace and it is not clear that the relatively small change in otolith size observed here in the highest $\mathrm{CO}_{2}$ treatment would be sufficient to cause substantive effects on larval fish.

A number of studies have shown that physiological stress can increase otolith asymmetry (Gagliano and McCormick, 2004; Payan et al., 2004); however, we found no evidence that ocean acidification is likely to decrease symmetry between left and right otoliths, even at relatively high $\mathrm{CO}_{2}$ concentrations. In fact, there was a trend for smaller differences in otolith area and length between left and right otoliths in the highest $\mathrm{CO}_{2}$ treatment, and for there to be less variation among individuals (i.e. lower sample variance). Increased calcification in the higher $\mathrm{CO}_{2}$ treatment might have tended to ameliorate differences in otolith shape and size, and thus been responsible for the apparent increase in symmetry between otoliths, both within and among individuals. Variation in the size and shape of left and right otoliths may affect the ability of individuals to detect and localize sound (Popper 
and $\mathrm{Lu}, 2000$; Gagliano et al., 2008) and decreased otolith symmetry has been associated with higher mortality rates in larval reef fishes (Gagliano et al., 2008). Consequently, any trend toward increased symmetry, such as that observed here, is unlikely to have a negative impact on individual fitness.

Otolith circularity was the only trait that varied significantly with fish length. There was a linear relationship between SL and circularity, indicating a shift from a squareshaped boundary in smaller fish towards a more triangular shape in larger fish. Otolith deposition does not occur evenly around the otolith, instead, growth often occurs more rapidly on one axis than the other, leading to an otolith that is increasingly more elongate and triangular in shape (Gagliano and McCormick, 2004; Green et al., 2009). Otolith growth is often correlated with somatic growth and therefore larger, faster growing fish within treatments may be expected to have a more triangular otolith profile, as observed.

This is the first study to examine the potential effects of ocean acidification on otolith chemistry and we found no effects of altered seawater carbonate chemistry on the elemental chemistry of the otoliths. Elemental ratios of all five elements were within the range typically reported for aragonitic marine fish otoliths (Campana and Thorrold, 2001). Although sample sizes were relatively small (5-7 individuals per treatment) the low variance and consistency of results suggests that a larger sample sizes would not have changed our interpretation in any meaningful way. We also found no visual evidence of vaterite or calcite in the any of the treatment otoliths, which if present would have resulted in relatively low Sr:Ca values (Veizer, 1983; Tomas and Geffen, 2003). Taken together, our data suggest that the larval clownfish were capable of regulating endolymphic fluid chemistry even in waters with $\mathrm{pH}$ values significantly lower than open ocean values.

Our results demonstrate a number of important points. First, the tendency for otolith size to increase and become less variable in the higher $\mathrm{CO}_{2}$ treatment is consistent with an effect on otolith development caused by the physiological process of $\mathrm{pH}$ regulation in fishes. Further studies are required to pinpoint the exact processes involved. Second, our results indicate that otolith development in larval clownfishes is robust to the levels of ocean chemistry change that may occur over the next 50-100 years, even if higher levels are likely to influence otolith size. Finally, we emphasize that there is likely to be considerable variation among species in their sensitivity to elevated $\mathrm{CO}_{2}$ and reduced $\mathrm{pH}$. Determining the traits that make some species more susceptible than others will aid in making predictions about the longer-term and ecosystem level effects of ocean acidification.
Acknowledgements. Staff at James Cook University's experimental marine aquarium facility provided excellent logistical support. Brynn Devine assisted with otolith preparation. We thank two anonymous reviewers for helpful comments on the ms

Edited by: G. Herndl

\section{References}

Allemand, D., Mayer-Gostan, N., de Pontual, H., Boeuf, G., and Payan, P.: Fish otolith calcification in relation to endolymph chemistry, in: Handbook of Biomineralization - Biological Aspects and Structure Formation, edited by: Bäuerlein E., 291-308, Wiley-VCH, Weinheim, 2007.

Bath, G. E., Thorrold, S. R., Jones, C. M., Campana, S. E., McLaren, J. W., and Lam, J. W. H.: Strontium and barium uptake in aragonitic otoliths of marine fish, Geochim. Cosmochim. Acta, 64, 1705-1714, 2000.

Brauner, C. J.: Acid-base balance, in: Fish Larval Physiology, edited by: Finn, R. N., Kapoor, B. G., 185-198, Science Publishers, Enfield, 2009.

Brauner, C. J. and Baker, D. W.: Patterns of acid-base regulation during exposure to hypercarbia in fishes, in: Cardio -Respiratory Control in Vertebrates, edited by: Glass, M. L. and Wood, S. C., 43-63, Springer, Berlin, 2009.

Caldeira, K. and Wickett, M. E.: Ocean model predictions of chemistry changes from carbon dioxide emissions to the atmosphere and ocean, J. Geophys. Res., 110, C09S04, doi:10.1029/2004JC002671, 2005.

Campana, S. E.: How reliable are growth back-calculations based on otoliths? Can. J. Fish. Aquat. Sci., 47, 2219-2227, 1990.

Campana, S. E. and Thorrold, S. R.: Otoliths, increments, and elements: keys to a comprehensive understanding of fish populations? Can. J. Fish. Aquat. Sci., 58, 30-38, 2001.

Checkley, D. M., Dickson, A. G., Takahashi, M., Radich, J. A., Eisenkolb, N., and Asch, R.: Elevated $\mathrm{CO}_{2}$ enhances otolith growth in young fish, Science, 324, 1683-1683, doi:10.1126/science.1169806, 2009.

Claiborne, J. B., Edwards, S. L., and Morrison-Shetlar, A. I.: Acidbase regulation in fishes: Cellular and molecular mechanisms, J. Exp. Zool., 293, 302-319, 2002.

Dissard, D., Nehrke, G., Reichart, G. J., and Bijma, J.: Impact of seawater $\mathrm{pCO}_{2}$ on calcification and $\mathrm{Mg} / \mathrm{Ca}$ and $\mathrm{Sr} / \mathrm{Ca}$ ratios in benthic foraminifera calcite: results from culturing experiments with Ammonia tepida, Biogeosciences, 7, 81-93, doi:10.5194/bg-7-81-2010, 2010.

Doney, S. C., Fabry, V. J., Feely, R. A., and Kleypas, J. A.: Ocean acidification: The other $\mathrm{CO}_{2}$ problem, Annu. Rev. Mar. Sci., 1, 169-192, doi:10.1146/annurev.marine.010908.163834, 2009.

Dupont, S., Ortega-Martinez, O., and Thorndyke, M.: Impact of near future ocean acidification on echinoderms, Ecotoxicology, 19, 449-462, 2010.

Evans, D. H., Piermarini, P. M., and Choe, K. P.: The multifunctional fish gill: Dominant site of gas exchange, osmoregulation, acid-base regulation, and excretion of nitrogenous waste, Physiol. Rev., 85, 97-177, doi:10.1152/physrev.00050.2003, 2005.

Fabry, V. J., Seibel, B. A., Feely, R. A., and Orr, J. C.: Impacts of ocean acidification on marine fauna and ecosystem processes, 
ICES J. Mar. Sci., 65, 414-432, doi:10.1093/icesjms/fsn048, 2008.

Feely, R. A., Sabine, C. L., Lee, K., Berelson, W., Kleypas, J., Fabry, V. J., and Millero, F. J.: Impact of anthropogenic $\mathrm{CO}_{2}$ on the $\mathrm{CaCO}_{3}$ system in the oceans, Science, 305, 362-366, 2004.

FitzGerald, J. L., Thorrold, S. R., Bailey, K. M., Brown, A., and Severin, K. P.: Elemental signatures in otoliths of larval walleye Pollock (Theragra calcogramma) from the northeast Pacific Ocean, Fish. Bull. U.S., 102, 604-616, 2004.

Gagliano, M., and McCormick, M. I.: Feeding history influences otolith shape in tropical fish, Mar. Ecol. Prog. Ser., 278, 291296, 2004.

Gagliano, M., Depczynski, M., Simpson, S. D., and Moore, J. A. Y.: Dispersal without errors: symmetrical ears tune into the right frequency for survival, Proc. R. Soc. B., 275, 527-534, doi:10.1098/rspb.2007.1388, 2008.

Gattuso, J.-P., Frankignoulle, M., Bourge, I., Romaine, S., and Buddemeier, R. W.: Effect of calcium carbonate saturation of seawater on coral calcification, Global Planet. Change, 18, 37-46, 1998.

Gazeau, F., Quiblier, C., Jansen, J. M., Gattuso, J.-P., Middelburg, J. J., and Heip, C. H. R.: Impact of elevated $\mathrm{CO}_{2}$ on shellfish calcification, Geophys. Res. Lett., 34, L07603, 2007.

Green, B. S, Mapstone, B. D., Carlos, G., and Begg, G. A.: Introduction to otoliths and fisheries in the tropics, in: Tropical Fish Otoliths: Information for Assessment, Management and Ecology, edited by: Green, B. S, Mapstone, B. D, Carlos, G., and Begg, G. A Springer, Green, Mapstone, Carlos and Begg, 1-22, Springer, Dordrecht, 2009.

Helfman, G. S., Collette, B. B., Facey, D. E.: The Diversity of Fishes, Blackwell Science, Malden, 1997.

Herfort, L., Thake, B., and Taubner, I.: Bicarbonate stimulation of calcification and photosynthesis in two hermatypic corals, J. Phycol., 44, 91-98, doi:10.1111/j.1529-8817.2007.00445.x, 2008.

Hoegh-Guldberg, O., Mumby, P. J., Hooten, A. J., Steneck, R. S., Greenfield, P., Gomez, E., Harvell, C. D., Sale, P. F., Edwards, A. J., Caldeira, K., Knowlton, N., Eakin, C. M., Iglesias-Prieto, R., Muthiga, N., Bradbury, R. H., Dubi, A., and Hatziolos, M. E.: Coral reefs under rapid climate change and ocean acidification, Science, 318, 1737-1742, doi:10.1126/science.1152509, ISSN:0036-8075 2007.

Hofmann, G. E., Barry, J. P., Edmunds, P. J., Gates, R. D., Hutchins, D. A., Klinger, T., and Sewell, M. A.: The effects of ocean acidification on calcifying oorganisms in marine ecosystems: an organism-to-ecosystem perspective, Annu. Rev. Ecol. Syst., 41, 127-147, 2010.

Ishimatsu, A., Hayashi, M., and Kikkawa, T.: Fishes in high$\mathrm{CO}_{2}$, acidified oceans, Mar. Ecol.-Prog. Ser., 373, 295-302, doi:10.3354/meps07823, 2008.

Kleypas, J. A. and Yates, K. K.: Coral reefs and ocean acidification, Oceanography, 22, 108-117, 2009.

Kroeker, K. J., Kordas, R. L., Crim, R. N., and Singh, G. G.: Meta-analysis reveals negative yet variable effects of ocean acidification on marine organisms, Ecol. Lett., 13, 1419-1434, doi:10.1111/j.1461-0248.2010.01518.x, 2010.

Langer, G., Nehrke, G., Probert, I., Ly, J., and Ziveri, P.: Strain-specific responses of Emiliania huxleyi to changing seawater carbonate chemistry, Biogeosciences, 6, 2637-2646, doi:10.5194/bg-6-2637-2009, 2009.
Lestrel, P. E.: Fourier Descriptors and their Application in Biology, Cambridge University Press, 1997.

Martin, G. B. and Thorrold, S. R: Temperature and salinity effects on magnesium, manganese and barium in the otoliths of larval spot (Leiostomus xanthurus), Mar. Ecol. Prog. Ser., 293, 223232, 2005.

Meehl, G. A., Stocker, T. F., Collins, W. D., Friedlingstein, P., Gaye, A. T., Gregory, J. M., Kitoh, A., Knutti, R., Murphy, J. M., Noda, A., Raper, S. C. B., Watterson, I. G., Weaver, A. J., and Zhao, Z.-C.: Global climate projections, in: Climate Change 2007: The Physical Science Basis, Contribution of Working Group I to the Fourth Assessment Report of the Intergovernmental Panel on Climate Change, edited by: Solomon, S., Qin, D., Manning, M. et al., 747-845, Cambridge University Press, Cambridge, UK, 2007.

Melzner, F., Gutowska, M. A., Langenbuch, M., Dupont, S., Lucassen, M., Thorndyke, M. C., Bleich, M., and Pörtner, H.-O.: Physiological basis for high $\mathrm{CO}_{2}$ tolerance in marine ectothermic animals: pre-adaptation through lifestyle and ontogeny?, Biogeosciences, 6, 2313-2331, doi:10.5194/bg-6-2313-2009, 2009.

Millero, F. J., Graham, T. B., Huang, F., Bustos-Serrano, H., and Pierrot, D.: Dissociation constants of carbonic acid in seawater as a function of salinity and temperature, Mar. Chem, 100, 8094, 2006.

Munday, P. L. and Wilson, S. K.: Comparative efficacy of clove oil and other chemicals in anaesthetisation of Pomacentrus amboinensis, a coral reef fish. J. Fish. Biol., 51, 931-938, 1997.

Munday, P. L., Hodges, A., Choat, J. H., and Gust, N.: Sexspecific growth effects in protogynous hermaphrodites, Can. J. Fish. Aquatic Sci., 61, 323-327, 2004.

Munday, P. L., Jones, G. P., Pratchett, M. S., and Williams, A. J.: Climate change and the future for coral reef fishes, Fish Fish., 9, 261-285, 2008.

Munday, P. L., Dixson, D. L., Donelson, J. M., Jones, G. P., Pratchett, M. S., Devitsina, G. V., and Doving, K. B.: Ocean acidification impairs olfactory discrimination and homing ability of a marine fish, Proc. Natl. Acad. Sci. U.S.A., 106, 1848-1852, doi:10.1073/pnas.0809996106, 2009.

Munday, P. L., Dixson, D. L., McCormick, M. I., Meekan, M., Ferrari, M. C. O., and Chivers, D. P.: Replenishment of fish populations is threatened by ocean acidification, Proc. Natl. Acad. Sci. U.S.A., 107, 12930-12934, doi:10.1073/pnas.1004519107, 2010.

Munday, P. L., Gagliano, M., Donelson, J. M., Dixson, D. L., and Thorrold, S. R.: Ocean acidification does not affect the early life history development of a tropical marine fish, Mar. Ecol. Prog. Ser., 423, 211-221, 2011.

Orr, J. C., Fabry, V. J., Aumont, O., Bopp, L., Doney, S. C., Feely, R. A., Gnanadesikan, A., Gruber, N., Ishida, A., Joos, F., Key, R. M., Lindsay, K., Maier-Reimer, E., Matear, R., Monfray, P., Mouchet, A., Najjar, R. G., Plattner, G. K., Rodgers, K. B., Sabine, C. L., Sarmiento, J. L., Schlitzer, R., Slater, R. D., Totterdell, I. J., Weirig, M. F., Yamanaka, Y., and Yool, A.: Anthropogenic ocean acidification over the twenty-first century and its impact on calcifying organisms, Nature, 437, 681-686, doi:10.1038/nature04095, 2005.

Pankhurst, N. W. and Munday, P. L.: Effects of climate change on fish reproduction and early life history stages, Mar. Freshwater Res., in press, 2011. 
Payan, P., Kossmann, H., Watrin, A., MayerGostan, N., and Boeuf, G.: Ionic composition of endolymph in teleosts: Origin and importance of endolymph alkalinity, J. Exp. Biol., 200, 1905-1912, 1997.

Payan, P., Borelli, G., Boeuf, G., and Mayer-Gostan, N.: Relationship between otolith and somatic growth: consequence of starvation on acid-base balance in plasma and endolymph in the rainbow trout Oncorhynchus mykiss, Fish Physiol. Biochem., 19, 3541, 1998.

Payan, P., Edeyer, A., Pontual, H., Borelli, G., Mayer-Gostan, N.: Chemical composition of saccular endolymph and otolith in fish inner ear: lack of spatial uniformity, Am. J. Physiol., 277, R123R131, 1999.

Payan, P., De Pontual, H., Edeyer, A., Borelli, G., Boeuf, G., and Mayer-Gostan, N.: Effects of stress on plasma homeostasis, endolymph chemistry, and check formation during otolith growth in rainbow trout (Oncorhynchus mykiss), Can. J. Fish. Aquat. Sci., 61, 1247-1255, doi:10.1139/f04-059, 2004.

Popper, A. N. and Lu, Z.: Structure-function relationships in fish otolith organs, Fisheries Res., 46, 16-25, 2000.

Pörtner, H. O., Langenbuch, M., and Michaelidis, B.: Synergistic effects of temperature extremes, hypoxia, and increases in $\mathrm{CO}_{2}$ on marine animals: From Earth history to global change, J. Geophys. Res.-Oceans, 110, C09S10, doi:10.1029/2004jc002561, 2005.

Pörtner, H. O. and Farrell, A. P.: Physiology and climate change, Science, 322, 690-692, doi:10.1126/science.1163156, 2008.

Raupach, M. R., Marland, G., Ciais, P., Le Quere, C., Canadell, J. G., Klepper, G., and Field, C. B.: Global and regional drivers of accelerating $\mathrm{CO}_{2}$ emissions, Proc. Natl. Acad. Sci. U.S.A., 104, 10288-10293, doi:10.1073/pnas.0700609104, 2007.
Riebesell, U., Zondervan, I., Rost, B., Tortell, P. D., Zeebe, R. E., and Morel, F. M. M.: Reduced calcification of marine plankton in response to increased atmospheric $\mathrm{CO}_{2}$, Nature, 407, 364-367, 2000.

Ries, J. B., Cohen, A. L., and McCorkle, D. C.: Marine calcifiers exhibit mixed responses to $\mathrm{CO}_{2}$-induced ocean acidification, $\mathrm{Ge}$ ology, 37, 1131-1134, doi:10.1130/g30210a.1, 2009.

Romanek, C. S. and Gauldie, R. W.: A predictive model of otolith growth in fish based on the chemistry of the endolymph, Comp. Biochem. Physiol. A, 114, 71-79, 1996.

Sturgeon, R. E., Willie, S. N., Yang, L., Greenberg, R., Spatz, R. O., Chen, Z., Scriver, C., Clancy, V., Lam, J. W., and Thorrold, S. R.: Certification of a fish otolith reference material in support of quality assurance for trace element analysis, J. Anal. Atom. Spectrom., 20, 1067-1071, 2005.

Takagi, Y.: Otolith formation and endolymph chemistry: a strong correlation between the endolymph saturation state and $\mathrm{pH}$ in the endolymph of the trout otolith organ, Mar. Ecol. Prog. Ser., 231, 237-245, 2002.

Thorrold, S. R. and J. A. Hare.: Otolith applications in reef fish ecology, in: Advances in the Ecology of Fishes on Coral Reefs, edited by: Sale, P. F., 243-264. Academic Press, 2002.

Tomas, J. and Geffen, A. J.: Morphology and composition of aragonite and vaterite otoliths of deformed laboratory reared juvenile herring from two populations, J. Fish Biol. 63, 1383-1401, 2003.

Veizer, J.: Trace elements and isotopes in sedimentary carbonates, Reviews in Mineralogy and Geochem., 11, 265-299, 1983.

Younker, J. L. and Ehrlich, R.: Fourier biometrics: harmonic amplitudes as multivariate shape descriptors, Systematic Zool., 26, 336-342. 1977. 